\title{
APAKAH FINANCIAL DAN OPERATIONAL HEDGING EFEKTIF MENGURANGI EKSPOSUR NILAI TUKAR?
}

\author{
Angga Sasmitapura* \\ Hamfri Djajadikerta \\ Universitas Katolik Parahyangan, Jl. Ciumbuleuit No. 94, Bandung \\ *angga.sasmitapura@unpar.ac.id
}

\author{
A R T I C L E I N F O \\ Article history: \\ Received October 5, 2020 \\ Revised November 4, 2020 \\ Accepted November 24, 2020
}

Key words:

Exchange Rate Exposure, Derivative,

Financial Hedging, Operational Hedging

DOI:

https://doi.org/10.33508/jako.v13i1.2758

\begin{abstract}
A B S T R A C T
In the midst of regulators' efforts to deepen the market by encouraging foreign exchange derivative transactions, this study aims to observe the effect of these derivative instruments from company perspective in reducing exchange rate exposures. In addition to hedge using derivative instruments (financial hedging), this study also observed hedging performed through firm's operational activity (operational hedging) with control variables of export sales and foreign debt. The research object is manufacturing companies listed in IDX (Indonesia Stock Exchange) during 2010-2018 using panel data regression as data analysis method. Empirical results show that financial hedging reduce exchange rate exposures faced by companies while operational hedging has no effect. Export sales provide positive exchange rate exposures and foreign debt provide negative exchange rate exposures.
\end{abstract}

\begin{abstract}
A B S T R A K
Di tengah upaya regulator melakukan pendalaman pasar dengan mendorong transaksi valas derivatif, penelitian ini bertujuan untuk mengamati pengaruh penggunaan instrumen derivatif tersebut dari perspektif perusahaan dalam mengurangi eksposur nilai tukar. Selain lindung nilai dengan instrumen derivatif (financial hedging), penelitian ini juga mengamati lindung nilai melalui kegiatan operasional perusahaan (operational hedging) dengan variabel kontrol berupa penjualan ekspor dan utang dalam mata uang asing. Objek penelitian adalah perusahaan manufaktur yang terdaftar di BEI (Bursa Efek Indonesia) selama tahun 2010-2018 dengan menggunakan regresi data panel sebagai metode analisis data. Hasil empiris menunjukkan bahwa financial hedging mengurangi eksposur nilai tukar yang dihadapi perusahaan sedangkan operational hedging tidak berpengaruh. Variabel penjualan ekspor menimbulkan eksposur nilai tukar positif dan utang dalam mata uang asing menimbulkan eksposur nilai tukar negatif.
\end{abstract}

\section{PENDAHULUAN}

Dominasi mata uang USD dalam perdagangan internasional menimbulkan ketergantungan ekonomi yang tinggi terhadap mata uang tersebut yang dapat meningkatkan risiko kerentanan eksternal terhadap shock. Hal tersebut dapat berdampak pada stabilitas makroekonomi, khususya melalui stabilitas nilai tukar Rupiah (Bank Indonesia, 2020). Upaya Bank Indonesia dalam menjaga stabilitas nilai tukar didukung salah satunya dengan struktur pasar valas yang semakin dalam dan efisien. Hal ini tidak terlepas dari kebijakan di tahun 2014 dimana Bank Indonesia men- dorong penggunaan transaksi valas derivatif sebagai instrumen lindung nilai yang efektif dan efisien. Adapun kebijakan tersebut dituangkan melalui penerbitan PBI No.16/21/PBI/2014 yang salah satunya mewajibkan perusahaan nonbank dengan selisih negatif antara aset dan liabilitas dalam mata uang asing sampai dengan batasan nominal tertentu untuk melakukan transaksi lindung nilai menggunakan instrumen derivatif (Bank Indonesia, 2014).

Penerbitan peraturan tersebut dilatarbelakangi oleh tingginya jumlah ULN (Utang Luar Negeri) swasta. Berdasarkan Statistik Utang Luar Negeri Indonesia (Kementrian Keuangan Republik Indonesia dan Bank Indonesia, 2020) ULN swasta pada akhir tahun 2014 (tahun dimana PBI diterbitkan) adalah 
sebesar USD 163,6 milyar dengan perbandingan terhadap total ULN adalah sebesar $55,8 \%$ yang merupakan porsi ULN swasta tertinggi sepanjang tahun 2009-2018 (Data ULN tahun 2009-2018 disajikan pada Lampiran). Dari ULN swasta tersebut, sebesar $74,4 \%$ didominasi oleh perusahaan non bank yaitu sebesar USD 121,8 milyar. Tingkat ULN dalam mata uang asing yang tinggi dapat memberikan dampak terhadap kinerja keuangan perusahaan apabila nilai tukar berfluktuasi secara signifikan. Gambar 1 dibawah ini menunjukkan grafik pergerakkan nilai tukar USD terhadap IDR sepanjang tahun 2010-2018 dengan kecenderungan terdepresiasinya IDR dalam jangka panjang. Melemahnya mata uang IDR akan meningkatkan beban pembayaran bunga maupun pokok utang sehingga berpotensi mengakibatkan $f i-$ nancial distress yang berujung pada meningkatnya risiko gagal bayar (default), khususnya ketika sebagian besar pendapatan perusahaan diperoleh secara domestik.

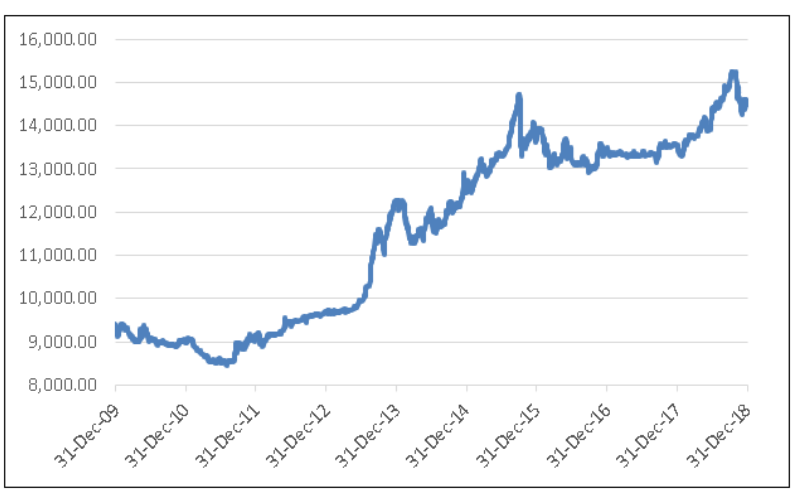

\section{Gambar 1. Grafik Pergerakkan Harian Nilai Tukar USD terhadap IDR Sepanjang Tahun 2010 - 2018}

Penggunaan instrumen derivatif sebagai lindung nilai diharapkan menjadi bentuk mitigasi risiko sehingga dapat mengurangi kerentanan perusahaan terhadap fluktuasi nilai tukar. Berbagai penelitian empiris terkait dengan penggunaan instrumen derivatif telah banyak dilakukan di mancanegara, seperti Allayannis dan Ofek (2001). Penelitian tersebut dilakukan terhadap sampel perusahaan non keuangan yang tergabung dalam indeks S\&P 500 dengan hasil penelitian menunjukkan bahwa penggunaan instrumen derivatif dapat mengurangi risiko nilai tukar secara signifikan. Hasil yang serupa ditunjukkan oleh Hagelin dan Pramborg (2004) dengan sampel perusahaan di Swedia. Penelitian yang dilakukan Chiang dan Lin (2007) terhadap perusahaan non keuangan di Taiwan menunjukkan bahwa penggunaan derivatif nilai tukar merupakan strategi lindung nilai yang efektif untuk jangka waktu 1 bulan, namun menjadi kurang efektif untuk periode waktu yang lebih panjang. Adapun Belghitar, Clark, dan Mefteh (2013) dengan sampel perusahaan di Perancis menunjukkan bahwa penggunaan instrumen derivatif mengurangi eksposur nilai tukar yang berdampak positif maupun negatif. Di Indonesia sendiri, penelitian sehubungan dengan penggunaan instrumen derivatif yang dikaitkan dengan shareholder value telah dilakukan oleh Suriawinata (2004). Hasil penelitian menunjukkan bahwa kebijakan lindung nilai yang diproksikan dengan jumlah nosional instrumen derivatif merupakan value enhancing activity. Hal ini menunjukkan instrumen derivatif yang digunakan perusahaan dapat mengatasi eksposur nilai tukar sehingga memberikan nilai tambah bagi pemegang saham. Adapun penelitian yang dilakukan oleh Indawan, dkk. (2015) dengan sampel penelitian berupa perusahaan non keuangan selama periode 2005-2011 menunjukkan bahwa penggunaan instrumen derivatif belum dapat mempengaruhi net worth dan kinerja perusahaan secara signifikan. Hal ini mengindikasikan belum adanya dorongan kuat bagi perusahaan untuk melakukan lindung nilai terhadap eksposur nilai tukar. Penelitian tersebut didukung juga dengan data yang menunjukkan bahwa transaksi derivatif yang dilakukan perusahaan non keuangan masih sangat terbatas.

Lindung nilai terhadap eksposur nilai tukar tentunya tidak hanya dapat dilakukan melalui penggunaan instrumen derivatif atau yang umum disebut dengan financial hedging, tetapi dapat dilakukan juga melalui kegiatan operasional perusahaan atau disebut operational hedging. Pantzalis, Simkins dan Laux (2001) dengan sampel perusahaan multinasional di US menunjukkan bahwa perusahaan dengan jaringan operasional yang tersebar di banyak negara memiliki eksposur nilai tukar yang lebih rendah. Penelitian Carter, Pantzalis dan Simkins (2003) menunjukkan bahwa baik operational dan financial hedging dapat secara efektif mengurangi eksposur nilai tukar. Hutson dan Laing (2014) juga menunjukkan bahwa baik operational maupun financial hedging secara signifikan mengurangi eksposur nilai tukar, namun ketika terjadi krisis keuangan justru financial hedging tidak seefektif operational hedging. Terhadap sampel perusahaan di Jepang, Ito, dkk. (2016) menunjukkan bahwa eksposur nilai tukar akan meningkat seiring dengan tingginya porsi penjualan yang dilakukan menggunakan mata uang 
USD, namun akan berkurang dengan adanya financial dan operational hedging. Hasil yang berbeda ditunjukkan oleh Allayannis, Ihrig, dan Weston (2001) dimana operational hedging tidak mengurangi eksposur nilai tukar jika tidak disertai dengan financial hedging sehingga bukan merupakan substitusi yang efektif dalam mengelola risiko keuangan. Chiang dan Lin (2007) mengungkapkan hal serupa dimana operational hedging tidak berkontribusi dalam mengurangi eksposur nilai tukar.

Penelitian ini dilakukan sejalan dengan upaya Bank Indonesia mendorong transaksi valas derivatif lindung nilai. Selain itu, penelitian ini pun dilakukan mengingat belum banyaknya penelitian di Indonesia yang mengamati keterkaitan penggunaan instrumen derivatif terhadap eksposur nilai tukar. Penelitian sebelumnya lebih banyak mengamati pengaruh instrumen derivatif terhadap nilai perusahaan. Oleh karena itu, penelitian ini dibuat dengan rumusan masalah yaitu apakah financial hedging dapat mengurangi eksposur nilai tukar yang dihadapi perusahaan di Indonesia. Kemudian apakah operational hedging juga dapat turut mengurangi eksposur nilai tukar. Penelitian ini menggunakan variabel kontrol berupa penjualan ekspor dan utang dalam mata uang asing. Perusahaan manufaktur dipilih sebagai objek penelitian dikarenakan berdasarkan Statistik Utang Luar Negeri Indonesia, pada tahun 2018 sektor manufaktur memiliki tingkat ULN kedua terbesar setelah sektor jasa keuangan dan asuransi (Kementrian Keuangan Republik Indonesia dan Bank Indonesia, 2020).

\section{KAJIAN LITERATUR DAN PENGEMBANGAN HIPOTESIS}

Kajian Literatur

Relevansi Manajemen Risiko

Teori dari Modigliani dan Miller (yang umum disebut MM) pada tahun 1958 mengungkapkan bahwa manajemen risiko merupakan praktik yang tidak relevan dimana nilai suatu perusahaan tidak bergantung pada kebijakan keuangan yang dilakukan oleh perusahaan tersebut (Jorion, 2011). Hal ini dikarenakan dalam mengelola risiko keuangan, investor dapat membentuk portofolio yang terdiversifikasi, sehingga kebijakan keuangan yang dilakukan perusahaan tidak akan memberikan nilai tambah bagi investor. Meskipun demikian, teori MM didasarkan pada asumsi bahwa tidak terdapat friksi pasar seperti pajak, biaya dari financial distress, information assymetric, dan biaya transaksi. Praktik manajemen risiko dapat memberikan manfaat terhadap nilai perusahaan apabila dapat mengurangi biaya-biaya yang muncul sebagai akibat tingginya variabilitas arus kas (Stulz, 1996) seperti biaya kebangkrutan (melalui pengurangan variabilitas arus kas yang mengurangi potensi financial distress), tambahan biaya yang dibayarkan kepada para pemangku kepentingan (melalui pengurangan kompensasi yang diasosiasikan dengan tingginya risiko yang dihadapi perusahaan), serta beban pajak (melalui penghematan pajak yang diperoleh dari pengurangan volatilitas laba perusahaan). Salah satu upaya yang dapat dilakukan perusahaan dalam mengurangi variabilitas arus kas adalah dengan melakukan lindung nilai terhadap risiko keuangan seperti volatilitas nilai tukar. Selain itu, perilaku riskaverse dari manajemen juga mendorong perusahaan untuk melakukan lindung nilai dalam rangka mengoptimalkan nilai perusahaan dengan dasar bahwa kompensasi manajemen merupakan fungsi dari nilai perusahaan (Smith dan Stulz, 1985).

\section{Eksposur Nilai Tukar}

Madura (2018) menjelaskan bahwa terdapat tiga bentuk eksposur nilai tukar, yaitu transaction exposure, economic exposure, dan translation exposure. Transaction exposure terjadi ketika nilai dari suatu transaksi di masa depan yang dilakukan perusahaan dalam mata uang asing dipengaruhi oleh pergerakkan nilai tukar. Economic exposure merupakan sensitivitas dari keseluruhan arus kas perusahaan yang disebabkan oleh pergerakkan nilai tukar, baik yang disebabkan oleh transaction exposure maupun sebab lainnya yang bersifat non-transaksional seperti kompetisi global. Translation exposure merupakan dampak fluktuasi nilai tukar pada penjabaran laporan keuangan yang terjadi ketika perusahaan induk melakukan konsolidasi laporan keuangan anak perusahaan yang disusun menggunakan mata uang yang berbeda dengan mata uang perusahaan induk.

Eksposur nilai tukar dapat diukur menggunakan analisis regresi seperti pada model yang disampaikan oleh Adler dan Dumas (1984). Melalui analisis regresi dengan return saham sebagai variabel dependen dan perubahan nilai tukar sebagai variabel independen, maka dapat diketahui seberapa besar nilai perusahaan berubah sebagai akibat fluktuasi nilai tukar. Berikut merupakan model Adler dan Dumas (1984) dalam mengukur eksposur nilai tukar:

$$
R_{i}=\alpha_{i}+\delta_{i} X R+\varepsilon_{i}
$$

Dimana $R_{i}$ merupakan return saham dari perusahaan i, $X R$ merupakan persentase perubahan nilai tukar, dan $\delta_{i}$ merupakan perubahan nilai perusahaan sebagai akibat fluktuasi nilai tukar. 
Untuk membantu mengendalikan faktor makroekonomi lainnya yang dapat berpengaruh terhadap return saham, banyak penelitian seperti Jorion (1990), Allayannis dan Ofek (2001), Pantzalis, Simkins dan Laux (2001), Carter, Pantzalis dan Simkins (2003), Hagelin dan Pramborg (2004), Chiang dan Lin (2007), serta Chue dan Cook (2008) memasukkan return portofolio pasar, sehingga model pengukuran eksposur nilai tukar menjadi sebagai berikut:

$$
R_{i}=\alpha_{i}+\beta_{i} R_{m}+\gamma_{i} X R+\varepsilon_{i}
$$

Dimana $R_{i}$ merupakan return saham dari perusahaan i, $X R$ merupakan persentase perubahan nilai tukar, $R_{m}$ merupakan return portofolio pasar, $\beta_{i}$ merupakan beta dari perusahaan i, dan $\gamma_{i}$ merupakan eksposur nilai tukar dari perusahaan i. Selain untuk mengendalikan pengaruh dari faktor makroekonomi lainnya, penggunaan return portofolio pasar juga dapat mengurangi secara signifikan residual yang timbul dari model regresi sehingga meningkatkan akurasi dari pengukuran eksposur nilai tukar (Bodnar dan Wong, 2003).

\section{Pengembangan Hipotesis}

\section{Financial Hedging}

Financial hedging merupakan lindung nilai yang dilakukan perusahaan dengan menggunakan instrumen derivatif. Apabila pergerakkan nilai tukar memberikan dampak negatif terhadap transaksi ataupun posisi yang dimiliki perusahaan, maka instrumen derivatif dengan posisi yang berlawanan akan memberikan dampak positif sehingga kedua dampak tersebut saling meniadakan (offset). Sebaliknya, apabila pergerakkan nilai tukar memberikan dampak positif atas transaksi maupun posisi perusahaan, instrumen derivatif di sisi lain akan memberikan dampak yang negatif. Kondisi ini akan mengurangi sensitivitas atau kerentanan perusahaan terhadap pergerakkan nilai tukar. Hal ini seperti yang disampaikan juga oleh Belghitar, Clark, dan Mefteh (2013) dimana hasil penelitian menunjukkan bahwa instrumen derivatif mengurangi eksposur nilai tukar baik yang berdampak positif maupun negatif. Penelitian lainnya seperti Allayannis, Ihrig, dan Weston (2001), Allayannis dan Ofek (2001), Carter, Pantzalis dan Simkins (2003), Hagelin dan Pramborg (2004), Chiang dan Lin (2007), Jorge dan Augusto (2011), serta Ito, dkk. (2016) mengungkapkan hal serupa, dimana financial hedging mengurangi eksposur nilai tukar yang dihadapi perusahaan.

Berdasarkan kajian teoritis diatas, maka peneliti membentuk hipotesis bahwa financial hedging dapat mengurangi eksposur nilai tukar.

\section{Operational Hedging}

Operational hedging mengacu pada lindung nilai yang dilakukan perusahaan melalui kegiatan operasionalnya. Perusahaan dapat melakukan lindung nilai eksposur nilai tukar dengan memanfaatkan operating flexibility. Operating flexibility merupakan kemampuan perusahaan dalam melakukan arbitrase pasar dengan cara merelokasi faktor produksi lintas negara dan transfer sumber daya melalui jaringan ataupun afiliasi yang ada di luar negeri (Pantzalis, Simkins dan Laux, 2001).

Pantzalis, Simkins dan Laux (2001) menggunakan 2 dimensi untuk menggambarkan struktur jaringan operasional perusahaan yang ada di luar negeri, yaitu: breadth dan depth. Breadth menunjukkan seberapa banyak perusahaan memiliki jaringan di berbagai negara asing, sedangkan depth menunjukkan seberapa tinggi tingkat konsentrasi dari jaringan yang dimiliki perusahaan pada beberapa negara. Hasil penelitian menunjukkan bahwa perusahaan dengan breadth yang tinggi memiliki eksposur nilai tukar yang lebih rendah, sedangkan perusahaan dengan depth yang tinggi memiliki eksposur yang lebih besar. Tingkat breadth yang tinggi menyebabkan perusahaan memiliki fleksibilitas dalam merelokasi kegiatan operasionalnya dari suatu negara ke negara lainnya dalam rangka merespon pergerakkan nilai tukar, sehingga memungkinkan perusahaan untuk mengelola risiko nilai tukar lebih baik. Sedangkan tingkat depth yang tinggi menunjukkan bahwa perusahaan lebih terkonsentrasi hanya pada beberapa negara, sehingga memiliki fleksibilitas yang rendah. Penelitian Carter, Pantzalis dan Simkins (2003) menunjukkan hal serupa, dimana operational hedging yang ditandai dengan tingginya breadth dan rendahnya depth, dapat secara efektif mengurangi eksposur nilai tukar.

Dalam penelitiannya, Hutson dan Laing (2014) menjelaskan alasan lain dimana operational hedging dapat mengurangi eksposur nilai tukar. Perusahaan yang beroperasi secara internasional secara tidak langsung melakukan currency diversification. Mengingat korelasi antar mata uang memiliki nilai kurang dari 1, maka akan terdapat pengurangan risiko nilai tukar secara keseluruhan. Hutson dan Laing (2014) juga menunjukkan bahwa operational hedging memberikan proteksi yang lebih baik daripada financial hedging khususnya pada masa-masa krisis.

Berdasarkan paparan diatas, maka peneliti membentuk hipotesis bahwa operational hedging dapat mengurangi eksposur nilai tukar. 


\section{Penjualan Ekspor}

Krugman dan Obstfeld seperti yang dikutip dalam Purnamawati dan Fatmawati (2013) mengungkapkan jika mata uang domestik mengalami pelemahan terhadap mata uang asing, maka barang yang diproduksi di dalam negeri menjadi relatif lebih murah bagi pihak asing. Sesuai dengan hukum permintaan, jika harga turun maka semakin banyak barang yang diminta. Hal ini akan meningkatkan penjualan perusahaan yang kemudian berkontribusi positif terhadap nilai perusahaan. Kondisi tersebut terjadi jika penjualan dilakukan dalam mata uang domestik. Madura (2018) menjelaskan jika penjualan dilakukan dalam mata uang asing dan mata uang domestik mengalami pelemahan, maka setiap penjualan yang dilakukan perusahaan dalam mata uang asing akan dikonversi menjadi mata uang domestik yang lebih besar. Hal ini akan meningkatkan arus kas masuk yang berkontribusi terhadap peningkatan kinerja keuangan perusahaan.

Paparan diatas menunjukkan bahwa penjualan ekspor berkontribusi dalam menimbulkan eksposur nilai tukar yang bernilai positif. Artinya, semakin tinggi penjualan ekspor, maka setiap peningkatan nilai tukar (mata uang asing menguat terhadap mata uang domestik) akan memberikan dampak positif yang semakin besar juga terhadap return saham perusahaan. Jika yang terjadi adalah melemahnya mata uang asing terhadap mata uang domestik, maka dengan semakin tingginya penjualan ekspor, setiap penurunan nilai tukar akan memberikan dampak negatif yang semakin besar juga terhadap return saham. Hal ini sejalan dengan berbagai penelitian yang telah dilakukan, seperti pada Jorion (1990), Allayannis dan Ofek (2001), serta Ito, dkk. (2016) yang menunjukkan bahwa penjualan ekspor berpengaruh positif terhadap eksposur nilai tukar.

Berdasarkan kajian teoritis diatas, maka peneliti membentuk hipotesis bahwa penjualan ekspor berpengaruh positif terhadap eksposur nilai tukar.

\section{Utang dalam Mata Uang Asing}

Pendanaan menggunakan utang dalam mata uang asing dapat menjadi strategi lindung nilai dengan menyeimbangkan dampak positif dan negatif yang timbul dari fluktuasi nilai tukar terhadap pendapatan perusahaan yang diterima dalam mata uang asing (Madura, 2018). Apabila mata uang asing menguat, maka perusahaan akan membutuhkan lebih banyak mata uang domestik untuk membayar utang. Dampak negatif ini akan diimbangi oleh dampak positif yang timbul dari peningkatan nilai atas pendapatan yang diterima dalam mata uang asing. Demikian sebaliknya, apabila mata uang asing melemah, maka pendapatan perusahaan dalam mata uang asing akan mengalami penurunan nilai. Dampak ini akan diimbangi oleh penurunan nilai utang yang perlu dibayar perusahaan dalam mata uang domestik.

Penelitian Kedia dan Mozumdar (2003) menunjukkan bahwa perusahaan menggunakan utang dalam berbagai mata uang dari negara dimana perusahaan beroperasi sebagai lindung nilai atas eksposur nilai tukar. Serupa dengan hal tersebut, Hagelin dan Pramborg (2004) menunjukkan adanya pengurangan eksposur nilai tukar yang dihadapi perusahaan sehubungan dengan penggunaan utang dalam mata uang asing.

Meskipun demikian, tidak seluruh perusahaan menggunakan utang dalam mata uang asing untuk tujuan lindung nilai. Hal ini ditunjukkan oleh Chiang dan Lin (2007) serta Chue dan Cook (2008) yang menunjukkan bahwa utang dalam mata uang asing justru meningkatkan eksposur nilai tukar. Kim, Tesar, dan Zhang (2015) terhadap perusahaan non keuangan di Korea Selatan, menunjukkan bahwa kepemilikan utang dalam mata uang asing khususnya yang berjangka pendek merupakan salah satu penyebab signifikan dimana perusahaan mengalami likuidasi atau kebangkrutan saat terjadinya krisis keuangan. Dampak kepemilikan utang dalam mata uang asing tersebut menjadi lebih kecil seiring dengan meningkatnya ukuran perusahaan.

Di Indonesia, penerbitan PBI No. 16/21/PBI/2014 (Bank Indonesia, 2014) dilatarbelakangi oleh tingginya ULN sektor swasta yang mana sebagian besar utang tersebut digunakan untuk membiayai kegiatan usaha berorientasi domestik dan menghasilkan pendapatan dalam mata uang domestik, sedangkan pembayaran ULN dilakukan dalam mata uang asing. Kondisi mismatch ini meningkatkan kerentanan perusahaan terhadap risiko nilai tukar. Apabila mata uang domestik mengalami pelemahan, maka beban pembayaran bunga maupun pokok utang akan menjadi lebih tinggi sehingga berpotensi mengakibatkan terjadinya financial distress yang berdampak negatif terhadap nilai perusahaan.

Hal tersebut menunjukkan bahwa utang dalam mata uang asing berkontribusi dalam menimbulkan eksposur nilai tukar yang bernilai negatif. Artinya, semakin tinggi utang dalam mata uang asing, maka setiap peningkatan nilai tukar (mata uang asing menguat terhadap mata uang domestik) akan 
memberikan dampak negatif yang semakin besar juga terhadap return saham perusahaan. Demikian sebaliknya, semakin tinggi utang dalam mata uang asing, maka setiap penurunan nilai tukar (mata uang asing melemah terhadap mata uang domestik) akan memberikan dampak positif yang semakin besar juga terhadap return saham.

Berdasarkan paparan diatas, maka peneliti membentuk hipotesis bahwa utang dalam mata uang asing berpengaruh negatif terhadap eksposur nilai tukar.

\section{Model Penelitian}

Model dalam penelitian ini dibangun dengan dasar pemikiran bahwa eksposur nilai tukar timbul dari kegiatan operasional perusahaan (melalui penjualan ekspor dan pendanaan dengan utang dalam mata uang asing), namun secara simultan dapat berkurang sehubungan dengan penggunaan lindung nilai (financial dan operational hedging) yang digambarkan sebagai berikut:

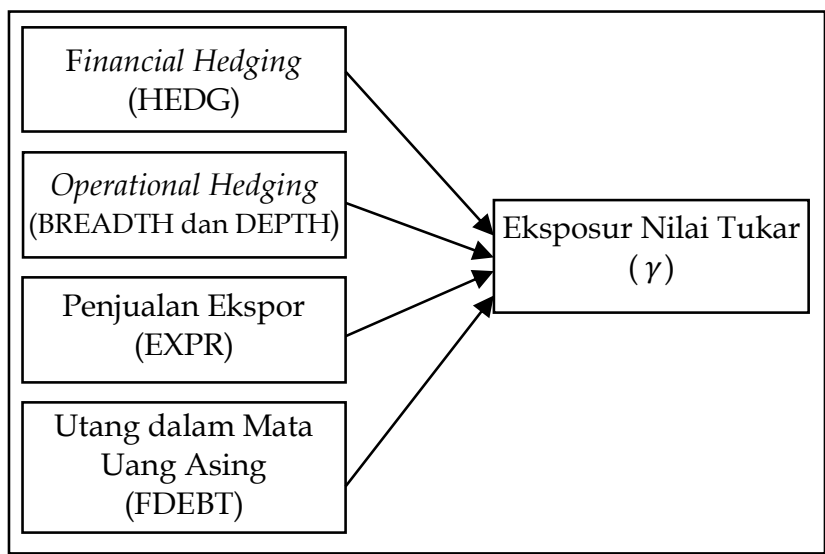

Gambar 2. Model Penelitian

Berikut merupakan model penelitian yang dituangkan dalam bentuk persamaan dengan maupun tanpa nilai absolut pada eksposur nilai tukar serta menggunakan 2 proksi operational hedging yang berbeda:

1) Menggunakan nilai absolut pada eksposur nilai tukar

$$
\begin{aligned}
\left|\gamma_{i t}\right|= & \beta_{0}+\beta_{1} H E D G_{i t}+\beta_{2} \text { BREADTH }_{i t}+ \\
& \beta_{3} E X P R_{i t}+\beta_{4} F D E B T_{i t}+e_{i t} \\
\left|\gamma_{i t}\right|= & \beta_{0}+\beta_{1} H E D G_{i t}+\beta_{2} D E P T H_{i t} \\
& \beta_{3} E X P R_{i t}+\beta_{4} F D E B T_{i t}+e_{i t}
\end{aligned}+
$$

2)Tanpa menggunakan nilai absolut pada eksposur nilai tukar

$$
\begin{aligned}
\gamma_{i t}= & \beta_{0}+\beta_{1} H E D G_{i t}+\beta_{2} B R E A D T H_{i t}+ \\
& \beta_{3} E R_{i t}+\beta_{4} F D E B T_{i t}+e_{i t}
\end{aligned}
$$

$$
\begin{aligned}
\gamma_{i t}= & \beta_{0}+\beta_{1} H E D G_{i t}+\beta_{2} D E P T H_{i t} \\
& \beta_{3} E X P R_{i t}+\beta_{4} F D E B T_{i t}+e_{i t}
\end{aligned}+
$$

Nilai absolut digunakan pada persamaan (3) dan (4) karena eksposur nilai tukar yang diukur melalui persamaan (2) dapat bernilai positif (peningkatan nilai tukar USD/IDR mengakibatkan return saham naik) maupun negatif (peningkatan nilai tukar USD/IDR mengakibatkan return saham turun). Penggunaan financial dan operational hedging ditujukan untuk mengurangi risiko nilai tukar dengan menyeimbangkan (offset) dampak positif dengan dampak negatif yang ditimbulkan dari pergerakkan nilai tukar. Dengan demikian, peneliti memprediksi bahwa lindung nilai akan mengurangi nilai absolut dari eksposur nilai tukar. Persamaan (5) dan (6) digunakan untuk mengamati variabel penjualan ekspor dan utang dalam mata uang asing terhadap jenis eksposur nilai tukar yang ditimbulkan, apakah positif atau negatif.

\section{METODE PENELITIAN}

Populasi dan Sampel Penelitian

Populasi dalam penelitian ini adalah perusahaan manufaktur yang terdaftar di BEI selama tahun 2010-2018. Jumlah perusahaan yang secara berturut-turut dari tahun 2010 sampai dengan tahun 2018 terdaftar pada sektor tersebut adalah sebanyak 116 perusahaan. Peneliti menggunakan purposive sampling dengan menerapkan kriteria pengambilan sampel sebagai berikut:

1) Tersedianya laporan keuangan yang diaudit untuk tahun buku yang berakhir pada tanggal 31 Desember tahun 2010 sampai dengan 2018.

2) Memiliki data yang lengkap dari variabelvariabel yang diteliti seperti penjualan ekspor dan utang dalam mata uang asing.

3) Saham perusahaan aktif diperdagangkan yang ditunjukkan dengan return saham perusahaan selama tahun tertentu tidak sama dengan nol.

Berdasarkan kriteria diatas, maka diperoleh ukuran sampel sebanyak 846 observasi dari 94 perusahaan selama periode 2010-2018.

\section{Variabel Penelitian}

Eksposur nilai tukar dalam penelitian ini mengacu pada economic exposure dikarenakan peneliti tertarik untuk mengamati dampak fluktuasi nilai tukar terhadap keseluruhan kinerja perusahaan yang tercermin dalam nilai perusahaan. Eksposur nilai tukar tersebut diukur melalui persamaan (2) dengan menggunakan data bulanan untuk setiap perusahaan pada setiap tahunnya. Nilai tukar yang digunakan adalah USD/IDR (berapa banyak 
nominal IDR untuk setiap satu USD) berdasarkan Kurs Transaksi Bank Indonesia pada situs www.bi.go.id. Sedangkan return portofolio pasar yang digunakan adalah Indeks Sektor Manufaktur yang diperoleh dari BEI mengingat objek penelitian ini adalah perusahaan manufaktur.

Data financial hedging diperoleh melalui pengamatan atas laporan keuangan perusahaan, khususnya pada bagian Catatan Atas Laporan Keuangan. Dikarenakan tidak semua perusahaan melaporkan jumlah nosional dari transaksi derivatif yang dilakukan sepanjang tahun tertentu, maka digunakan variabel dummy dengan nilai 1 jika perusahaan melakukan financial hedging dan bernilai 0 jika perusahaan tidak melakukan financial hedging. Untuk operational hedging, sejalan dengan peneliti sebelumnya seperti Allayannis, Ihrig, dan Weston (2001), serta Carter, Pantzalis dan Simkins (2003), maka penelitian ini menggunakan 2 proksi, yaitu breadth dan depth. Breadth diukur dari jumlah negara asing dimana perusahaan beroperasi melalui anak perusahaan. Depth diukur menggunakan indeks Hirschman-Herfindahl yang menunjukkan tingkat konsentrasi

Tabel 1. Ringkasan Variabel Penelitian

\begin{tabular}{|c|c|c|c|c|}
\hline No. & Variabel & Konsep Variabel & Indikator & Skala \\
\hline 1 & $\begin{array}{l}\text { Eksposur nilai tu- } \\
\text { kar } \\
\left(\gamma_{i t}\right)\end{array}$ & $\begin{array}{l}\text { Sensitivitas dari nilai perus- } \\
\text { ahaan yang disebabkan oleh } \\
\text { fluktuasi nilai tukar }\end{array}$ & $\begin{array}{l}\text { Koefisien regresi dari perubahan } \\
\text { nilai tukar terhadap nilai perus- } \\
\text { ahaan sesuai dengan persamaan } \\
\text { (2) }\end{array}$ & Rasio \\
\hline 2 & $\begin{array}{l}\text { Financial Hedging } \\
\text { (HEDG) }\end{array}$ & $\begin{array}{l}\text { Lindung nilai yang dilakukan } \\
\text { perusahaan dengan } \\
\text { menggunakan instrumen } \\
\text { derivatif nilai tukar }\end{array}$ & $\begin{array}{l}\text { Menggunakan variabel dummy: } \\
1=\text { melakukan financial hedging, } \\
0=\text { tidak melakukan financial } \\
\text { hedging }\end{array}$ & Nominal \\
\hline \multirow[t]{2}{*}{3} & \multirow[t]{2}{*}{$\begin{array}{l}\text { Operational hedg- } \\
\text { ing }\end{array}$} & \multirow{2}{*}{$\begin{array}{l}\text { Lindung nilai yang dilakukan } \\
\text { melalui kegiatan operasional } \\
\text { perusahaan dengan me- } \\
\text { manfaatkan } \\
\text { struktur atau jaringan perus- } \\
\text { ahaan di luar negeri }\end{array}$} & $\begin{array}{l}\text { Jumlah negara asing dimana pe- } \\
\text { rusahaan beroperasi melalui } \\
\text { anak perusahaan (BREADTH) }\end{array}$ & Rasio \\
\hline & & & $\begin{array}{l}\text { Tingkat konsentrasi dari } \\
\text { kegiatan operasional perusahaan } \\
\text { di berbagai negara melalui seba- } \\
\text { ran anak perusahaan, diukur } \\
\text { menggunakan indeks Hirsch- } \\
\text { man-Herfindahl sesuai dengan } \\
\text { persamaan (7) (DEPTH) }\end{array}$ & Rasio \\
\hline 4. & $\begin{array}{l}\text { Penjualan Ekspor } \\
\text { (EXPR) }\end{array}$ & $\begin{array}{l}\text { Penjualan yang dilakukan pe- } \\
\text { rusahaan keluar dari wilayah } \\
\text { Indonesia }\end{array}$ & $\begin{array}{l}\text { Rasio penjualan ekspor terhadap } \\
\text { total penjualan }\end{array}$ & Rasio \\
\hline 5. & $\begin{array}{l}\text { Utang dalam mata } \\
\text { uang asing } \\
\text { (FDEBT) }\end{array}$ & $\begin{array}{l}\text { Utang yang didenominasi da- } \\
\text { lam mata uang asing }\end{array}$ & $\begin{array}{l}\text { Rasio utang dalam mata uang as- } \\
\text { ing terhadap total aset. }\end{array}$ & Rasio \\
\hline
\end{tabular}

dari kegiatan operasional perusahaan di berbagai negara melalui sebaran anak perusahaan. Berikut merupakan formula untuk menghitung indeks Hirschman-Herfindahl:

Depth $_{i}=\sum_{j=1}^{k}\left[\frac{(\text { number of subsidiaries })_{j}}{(\text { total number of subsidiaries })_{i}}\right]^{2}$

Dimana k merupakan jumlah negara dimana perusahaan i beroperasi. Depth akan memiliki nilai mendekati 0 apabila suatu perusahaan memiliki anak perusahaan yang tersebar di banyak negara dan memiliki nilai 1 apabila perusahaan hanya beroperasi di satu negara. Adapun penjualan ekspor diukur dengan rasio penjualan ekspor terhadap total penjualan, sedangkan utang dalam mata uang asing diukur menggunakan rasio utang dalam mata uang asing terhadap total aset. Data-data ini diperoleh dari laporan keuangan.

Tabel 1 menyajikan ringkasan dari variabel penelitian yang digunakan.

\section{Teknik Analisis Data}

Teknik analisis yang digunakan adalah regresi data panel dengan jumlah data time series yang sama 
untuk setiap data cross section (balanced panel). Menurut Widarjono (2013), terdapat tiga pendekatan yang umum digunakan dalam model regresi data panel, yaitu common effect, fixed effect, dan random effect. Untuk mengetahui pendekatan mana yang paling sesuai untuk diterapkan pada data penelitian, maka akan dilakukan beberapa pengujian seperti Uji Chow dan Uji Lagrange Multiplier (LM).

Selain pengujian untuk menentukan pendekatan model regresi data panel mana yang akan digunakan, dalam penelitian ini juga dilakukan beberapa pengujian seperti analisis nilai statistik Durbin-Watson, White Test, dan Ramsey RESET Test untuk memastikan hasil penelitian terbebas dari masalah autokorelasi, heteroskedastisitas, dan kesalahan spesifikasi. Selanjutnya penelitian akan dilanjutkan dengan uji $\mathrm{F}$ untuk mengevaluasi tingkat signifikansi dari model serta uji $t$ untuk mengetahui pengaruh dari masing-masing variabel independen (financial hedging, operational hedging, penjualan ekspor, dan utang dalam mata uang asing) terhadap eksposur nilai tukar yang dilakukan untuk menjawab rumusan masalah dari penelitian ini.

\section{HASIL DAN PEMBAHASAN}

Hasil Penelitian

Statistik Deskriptif

Tabel 2 bagian A menyajikan statistik deskriptif untuk eksposur nilai tukar dalam nilai absolut. Tabel tersebut mengelompokkan analisis berdasarkan jenis eksposur (positif/negatif) dan penggunaan financial hedging. Dari 846 observasi, sebanyak 375 memiliki eksposur nilai tukar positif dan 471 memiliki eksposur nilai tukar negatif. Hal ini menunjukkan, ketika mata uang USD menguat terhadap mata uang IDR, maka lebih banyak perusahaan yang mengalami penurunan return saham daripada perusahaan yang mengalami peningkatan dengan proporsi sebesar $55 \%$ dan $45 \%$. Tidak terdapat perbedaan besarnya eksposur baik untuk observasi dengan eksposur nilai tukar positif maupun negatif yang ditunjukkan dari wilcoxon rank sum test dengan $p$-value sebesar 0,2887 . Sebanyak 176 dari 846 observasi (sebesar 20.80\%) menggunakan instrumen derivatif nilai tukar. Sesuai dengan dugaan awal, observasi dengan penggunaan derivatif memiliki rata-rata dan median eksposur nilai tukar yang lebih rendah $(2,0889$ dan 1,0597$)$ daripada observasi tanpa penggunaan derivatif $(2,6360$ dan 1,3215$)$. Perbedaan median ini signifikan pada taraf $10 \%$ (ditunjukkan dari $p$-value sebesar 0,0541 pada wilcoxon rank sum test).

Tabel 2. Statistik deskriptif

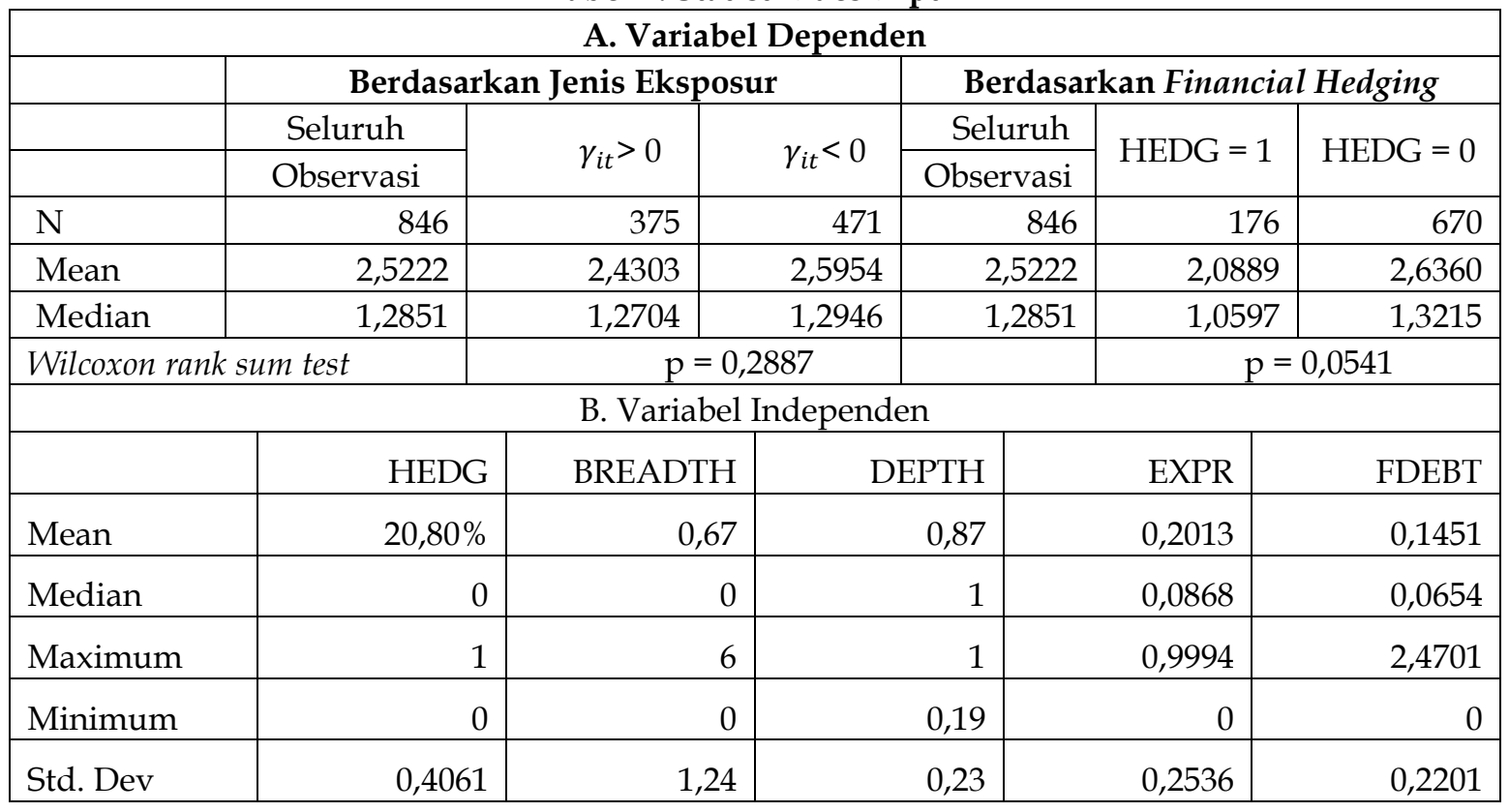


Tabel 2 bagian $b$ menyajikan statistik deskriptif untuk variabel-variabel independen. Nilai rata-rata variabel HEDG untuk sampel penelitian adalah sebesar 20,80\%. Penggunaan instrumen derivatif meningkat dari tahun ke tahun dimana pada tahun 2010 terdapat $15,96 \%$ perusahaan yang menggunakan instrumen derivatif dan meningkat menjadi sebesar $27,66 \%$ di tahun 2018. Peningkatan cukup signifikan terjadi di tahun 2015, tahun dimana PBI No. 16/21/PBI/ 2014 berlaku efektif pada tanggal 1 Januari 2015 (Bank Indonesia, 2014). Operational hedging yang diproksikan dengan BREADTH memiliki rata-rata sebesar 0,67 . Artinya, secara ratarata perusahaan dalam sampel penelitian memiliki kegiatan operasional di 0,67 negara asing melalui anak perusahaannya. Nilai tertinggi adalah 6 yang menunjukkan bahwa perusahaan memiliki anak perusahaan di 6 negara asing yang berbeda, sedangkan nilai terendah adalah 0 yang menunjukkan perusahaan tidak memiliki anak perusahaan di luar negeri. Proksi operational hedging lainnya, yaitu DEPTH yang menunjukkan sebaran anak perusahaan di berbagai negara, memiliki rata-rata sebesar 0,87 . Nilai tertinggi adalah 1 yang menunjukkan bahwa perusahaan hanya beroperasi di indonesia dan nilai terendah adalah 0,19 dimana perusahaan tersebut memiliki 7 anak perusahaan yang tersebar di 5 negara asing dan 2 anak perusahaan lainnya di
Indonesia. Variabel EXPR memiliki rata-rata sebesar $20,13 \%$. Nilai tertinggi adalah sebesar $99,94 \%$ yang menunjukkan bahwa perusahaan sangat bergantung pada pasar ekspor dan nilai terendah sebesar $0 \%$ yang menunjukkan perusahaan hanya melakukan penjualan di pasar domestik. Variabel FDEBT yang menunjukkan porsi aset perusahaan yang didanai oleh utang dalam mata uang asing memiliki rata-rata sebesar $14,51 \%$. Nilai tertinggi sebesar $247,01 \%$ yang menunjukkan bahwa utang dalam mata uang asing lebih besar daripada total aset, dimana perusahaan tersebut sedang mengalami defisiensi modal. Terdapat juga perusahaan yang tidak menggunakan utang dalam mata uang asing yang ditunjukkan dengan nilai FDEBT sebesar $0 \%$.

\section{Analisis Regresi}

Untuk menentukan pendekatan mana yang paling sesuai dalam estimasi regresi data panel, maka pada penelitian ini telah dilakukan beberapa pengujian seperti Uji Chow dan Uji Lagrange Multiplier (LM). Hasil pengujian tersebut menunjukkan bahwa pendekatan yang paling sesuai adalah common effect. Berikut merupakan hasil estimasi regresi untuk keempat model penelitian.

Tabel 3. Hasil Estimasi Regresi

\begin{tabular}{|l|c|c|c|c|}
\hline & $(\mathbf{3})$ & $\mathbf{( 4 )}$ & $\mathbf{( 5 )}$ & $\mathbf{( 6 )}$ \\
\hline Variabel dependen: & $\left|\gamma_{i t}\right|$ & $\left|\gamma_{i t}\right|$ & $\gamma_{i t}$ & $\gamma_{i t}$ \\
\hline Proksi operational hedging: & BREADTH & DEPTH & BREADTH & DEPTH \\
\hline C & 2.2310 & 2.2948 & -0.3314 & -0.6840 \\
\hline HEDG & $-0.4875^{*}$ & $-0.5201^{* *}$ & 0.1690 & 0.2097 \\
\hline & & & & \\
\hline BREADTH & -0.0378 & & -0.0003 & \\
\hline DEPTH & & -0.0827 & & 0.3761 \\
\hline EXPR & $1.0170^{* *}$ & $0.9548^{* *}$ & $0.9575^{*}$ & $1.0415^{* * *}$ \\
\hline FDEBT & $1.4697^{* * *}$ & $1.4832^{* * *}$ & $-1.8192^{* * *}$ & $-1.8143^{* * *}$ \\
\hline & & & & 0.0052 \\
\hline Adjusted R-squared & 0.0162 & 0.0160 & 0.0048 & $2.1006^{* *}$ \\
\hline F-statistic & $4.4696^{* * *}$ & $4.4392^{* * *}$ & $2.0245^{* *}$ & 1.9403 \\
\hline Durbin-Watson Stat & 2.0676 & 2.0692 & 1.9388 & 0.1430 \\
\hline p-value White Test & 0.1662 & 0.2054 & 0.1277 & 0.1595 \\
\hline p-value Ramsey RESET Test & 0.6932 & 0.6591 & 0.1907 & 846 \\
\hline \multicolumn{4}{|l|}{} \\
\hline Jumlah observasi & 846 & 846 & 846 & \\
\hline${ }^{* * *,+* *, *}$ menunjukkan signifikansi secara berturut-turut pada taraf $1 \%, 5 \%$, dan $10 \%$ & \\
\hline
\end{tabular}


Hasil estimasi regresi pada tabel 3. menunjukkan bahwa model penelitian terbebas dari permasalahan autokorelasi, heteroskedastisitas, dan kesalahan spesifikasi yang dapat dilihat pada nilai statistik Durbin-Watson yang berada diantara $\mathrm{d}_{\mathrm{u}}$ dan $4-\mathrm{d}_{\mathrm{u}}$ serta $p$-value dari White Test dan Ramsey RESET Test yang lebih besar dari 5\%. Adapun nilai dari statistik F untuk keempat model penelitian menunjukkan bahwa model signifikan pada taraf $1 \%$ dan $5 \%$. Hal ini menunjukkan bahwa variabel independen yang ada secara bersama-sama berpengaruh terhadap variabel eksposur nilai tukar. Namun demikian, nilai adjusted $R$-squared pada keempat model penelitian menunjukkan nilai rendah, yang artinya masih banyak variabel lainnya yang menjelaskan variasi dari eksposur nilai tukar yang tidak diamati dalam penelitian ini.

\section{Pembahasan}

\section{Pengaruh Financial Hedging terhadap Eksposur Nilai} Tukar

Hasil estimasi regresi pada tabel 3 untuk persamaan (3) dan (4) menunjukkan bahwa penggunaan instrumen derivatif nilai tukar berpengaruh negatif terhadap eksposur nilai tukar dalam nilai absolut. Nilai absolut tersebut menunjukkan bahwa penggunaan instrumen derivatif mengurangi eksposur nilai tukar yang bernilai positif maupun negatif, sehingga mengurangi kerentanan perusahaan terhadap fluktuasi nilai tukar. Hal ini menunjukkan bahwa upaya lindung nilai yang dilakukan perusahaan berjalan cukup efektif, dimana dapat mengurangi eksposur nilai tukar dalam nilai absolut sebesar 0,4875 dan 0,5201 . Hasil estimasi regresi juga menunjukkan bahwa instrumen derivatif nilai tukar mengurangi dampak fluktuasi nilai tukar yang ditimbulkan dari penjualan ekspor dan penggunaan utang dalam mata uang asing. Hal ini ditunjukkan dari koefisien regresi untuk EXPR dan FDEBT yang bernilai positif yang artinya kedua variabel tersebut meningkatkan eksposur nilai tukar dalam nilai absolut yang kemudian berkurang seiring dengan adanya HEDG. Hasil penelitian ini sejalan dengan Allayannis, Ihrig, dan Weston (2001), Allayannis dan Ofek (2001), Carter, Pantzalis dan Simkins (2003), Hagelin dan Pramborg (2004), Chiang dan Lin (2007), Jorge dan Augusto (2011), Belghitar, Clark, dan Mefteh (2013), serta Ito, dkk. (2016) yang menunjukkan bahwa penggunaan instrumen derivatif nilai tukar efektif mengurangi eksposur nilai tukar.
Pengaruh Operational Hedging terhadap Eksposur Nilai Tukar

Hasil estimasi regresi pada Tabel 3 untuk persamaan (3) dan (4) menunjukkan bahwa baik BREADTH dan DEPTH tidak berpengaruh secara signifikan terhadap eksposur nilai tukar. Sehingga dapat disimpulkan bahwa operational hedging tidak seefektif financial hedging dalam mengurangi risiko nilai tukar yang dihadapi perusahaan. Hasil penelitian ini sejalan dengan Allayannis, Ihrig, dan Weston (2001) yang mengungkapkan bahwa penyebaran geografis melalui penempatan anak perusahaan pada berbagai negara tidak mengurangi eksposur nilai tukar serta Chiang dan Lin (2007) yang menyimpulkan bahwa penggunaan operational hedging tidak dapat mengurangi eksposur nilai tukar bagi perusahaan-perusahaan di Taiwan. Peneliti menganalisis setidaknya terdapat beberapa faktor yang berpotensi menyebabkan tidak berpengaruhnya operational hedging, yaitu:

1) Serupa dengan Chiang dan Lin (2007), penyebaran anak perusahaan pada sampel penelitian lebih terkonsentrasi pada wilayah Asia yang memiliki mata uang yang cenderung bergerak dengan arah yang sama dengan mata uang IDR sehingga menjadi kurang efektif dalam mengurangi risiko nilai tukar secara keseluruhan.

2) Anak perusahaan yang dilaporkan dalam laporan keuangan belum tentu seluruhnya digunakan untuk kegiatan bisnis dan operasional, melainkan dapat juga beberapa anak perusahaan yang ada di luar negeri dibuat untuk tujuan perencanaan pajak.

3) Proksi BREADTH dan DEPTH dikembangkan berdasarkan anak perusahaan yang ada di luar negeri, dimana kegiatan operasional di luar negeri juga dapat dilakukan perusahaan dengan bentuk cabang operasional. Hal ini merupakan keterbatasan baik pada penelitian ini maupun pada penelitian sebelumnya dimana informasi mengenai cabang perusahaan sulit diperoleh karena tidak tersedia dalam laporan keuangan.

Pengaruh Penjualan Ekspor terhadap Eksposur Nilai Tukar

Tabel 3 persamaan (5) dan (6) menunjukkan bahwa penjualan ekspor berpengaruh positif terhadap eksposur nilai tukar pada taraf signifikansi $10 \%$ dan 5\%. Dengan kata lain, penjualan ekspor berkontribusi dalam menimbulkan eksposur nilai tukar yang bernilai positif. Eksposur nilai tukar pos- 
itif menunjukkan hubungan searah antara perubahan nilai tukar dengan return saham perusahaan. Apabila nilai tukar USD/IDR meningkat (mata uang USD menguat terhadap mata uang IDR), maka akan terjadi peningkatan return saham perusahaan. Sebaliknya, apabila nilai tukar USD/IDR turun (mata uang USD melemah terhadap mata uang IDR), maka return saham juga akan mengalami penurunan.

Penjualan ekspor yang dilakukan perusahaanperusahaan di Indonesia banyak dilakukan dalam mata uang asing seperti USD. Ketika mata uang USD menguat, maka hal ini akan menguntungkan perusahaan karena arus kas masuk yang diterima dalam mata uang asing akan dikonversi menjadi mata uang IDR dengan nilai yang lebih besar. Kondisi ini mengakibatkan perusahaan dengan tingkat penjualan ekspor yang tinggi akan menikmati keuntungan yang lebih besar juga sehingga menjadi lebih resilien dalam menghadapi dampak negatif lainnya yang mungkin timbul sebagai akibat terdepresiasinya mata uang domestik. Sebaliknya, perusahaan dengan tingkat penjualan ekspor yang tinggi justru berpotensi mengalami penurunan return saham jika mata uang USD melemah terhadap mata uang IDR.

Hasil penelitian ini sejalan dengan Jorion (1990), Allayannis dan Ofek (2001), serta Ito, dkk. (2016) dimana penjualan ekspor berpengaruh positif terhadap eksposur nilai tukar.

Pengaruh Utang dalam Mata Uang Asing terhadap Eksposur Nilai Tukar

Hasil estimasi regresi pada Tabel 3 persamaan (3) dan (4) menunjukkan bahwa utang dalam mata uang asing tidak digunakan perusahaan sebagai upaya lindung nilai seperti pada penelitian Kedia dan Mozumdar (2003) serta Hagelin dan Pramborg (2004). Penggunaan utang dalam mata uang asing tersebut justru meningkatkan kerentanan perusahaan terhadap risiko nilai tukar yang ditunjukkan dari koefisien regresi FDEBT yang bernilai positif dan signifikan terhadap eksposur nilai tukar dalam nilai absolut.

Eksposur nilai tukar yang ditimbulkan dari penggunaan utang dalam mata uang asing bernilai negatif seperti yang ditunjukkan pada Tabel 3 persamaan (5) dan (6) dan signifikan pada taraf 1\%. Eksposur nilai tukar negatif menunjukkan hubungan yang berlawanan antara perubahan nilai tukar dengan return saham perusahaan. Apabila nilai tukar USD/IDR meningkat (mata uang USD menguat terhadap mata uang IDR), maka return saham perus- ahaan akan mengalami penurunan. Sebaliknya, apabila nilai tukar USD/IDR turun (mata uang USD melemah terhadap mata uang IDR), maka return saham akan meningkat.

Sebagian besar perusahaan manufaktur di Indonesia berorientasi domestik. Hal ini dapat dilihat dari statistik deskriptif pada Tabel 2 dimana ratarata EXPR adalah sebesar $20,13 \%$ yang menunjukkan sebagian besar penjualan (yaitu 79,87\%) dilakukan di Indonesia. Adapun sebaran anak perusahaan yang ditunjukkan oleh proksi DEPTH memiliki nilai rata-rata sebesar 0,87. Angka ini cenderung mendekati nilai 1 yang menunjukkan bahwa perusahaan hanya beroperasi di satu negara, yaitu Indonesia. Penggunaan utang dalam mata uang asing sebagai sumber pendanaan kegiatan usaha yang berorientasi domestik akan meningkatkan risiko nilai tukar, khususnya ketika mata uang domestik mengalami pelemahan.

Hasil penelitian ini sejalan dengan Chiang dan Lin (2007), Chue dan Cook (2008), serta Kim, Tesar, dan Zhang (2015) yang menunjukkan bahwa utang dalam mata uang asing meningkatkan eksposur nilai tukar.

\section{Robustness Test}

Pada penelitian ini dilakukan robustness test dengan menggunakan return IHSG (Indeks Harga Saham Gabungan) sebagai proksi alternatif dari return portofolio pasar dalam pengukuran eksposur nilai tukar pada persamaan (2). Hasil estimasi regresi disajikan pada Tabel 4 dibawah. 
Tabel 4. Hasil Estimasi Regresi dengan Menggunakan Return IHSG sebagai Proksi Alternatif dari Return Portofolio Pasar

\begin{tabular}{|c|c|c|c|c|}
\hline & (3) & (4) & (5) & (6) \\
\hline Variabel dependen: & $\left|\gamma_{i t}\right|$ & $\left|\gamma_{i t}\right|$ & $\gamma_{i t}$ & $\gamma_{i t}$ \\
\hline Proksi operational hedging: & BREADTH & DEPTH & BREADTH & DEPTH \\
\hline $\mathrm{C}$ & 2.3425 & 2.3812 & 0.0572 & -0.0198 \\
\hline HEDG & $-0.3899^{*}$ & $-0.4207^{*}$ & -0.2065 & -0.1866 \\
\hline BREADTH & -0.0395 & & 0.0164 & \\
\hline DEPTH & & -0.0566 & & 0.0885 \\
\hline EXPR & $0.8257^{\text {** }}$ & $0.7674^{*}$ & $0.8374^{*}$ & $0.8762^{*}$ \\
\hline FDEBT & $0.7822^{*}$ & $0.7966^{*}$ & $-1.3210^{\text {** }}$ & $-1.3262^{* *}$ \\
\hline Adjusted R-squared & 0.0055 & 0.0053 & 0.0017 & 0.0017 \\
\hline F-statistic & $2.1663^{\star *}$ & $2.1294^{* *}$ & 1.3624 & 1.3622 \\
\hline Durbin-Watson Stat & 2.0894 & 2.0907 & 1.9569 & 1.9572 \\
\hline p-value White Test & 0.2714 & 0.3973 & 0.3011 & 0.3674 \\
\hline p-value Ramsey RESET Test & 0.7710 & 0.6320 & 0.2620 & 0.2375 \\
\hline Jumlah observasi & 846 & 846 & 846 & 846 \\
\hline
\end{tabular}

Hasil estimasi regresi pada Tabel 4 menunjukkan hasil yang cukup konsisten dengan Tabel 3 meskipun pada signifikansi yang lebih rendah. Hal ini menunjukkan bahwa tidak terdapat perbedaan yang berarti terhadap hasil penelitian jika eksposur nilai tukar diukur baik menggunakan return Indeks Sektor Manufaktur maupun IHSG. Selain itu, penelitian ini juga menggunakan dua proksi operational hedging, yaitu BREADTH dan DEPTH. Hasil estimasi regresi dari kedua proksi ini menunjukkan hasil yang sejalan (persamaan (3) dengan (4) serta persamaan (5) dengan (6).

\section{SIMPULAN}

Perusahaan dapat memiliki eksposur terhadap risiko nilai tukar yang timbul baik dari posisi neraca maupun penjualan ekspor yang dilakukan. Untuk mengelola risiko tersebut, perusahaan umumnya berupaya untuk menyeimbangkan posisi aset dan utang serta arus kas masuk dan arus kas keluar dalam mata uang asing. Apabila masih terdapat selisih, maka perusahaan dapat mempertimbangkan untuk menggunakan instrumen derivatif sebagai lindung nilai karena berdasarkan penelitian ini terbukti mampu mengurangi eksposur nilai tukar. Penggunaan financial hedging menjadi krusial khususnya bagi perusahaan dengan ketergantungan yang tinggi terhadap utang dalam mata uang asing. Sesuai dengan pembahasan sebe- lumnya, utang dalam mata uang asing menimbulkan eksposur nilai tukar yang bernilai negatif. Hal ini berpotensi memberikan dampak yang merugikan terhadap kinerja perusahaan mengingat berdasarkan data historis, nilai tukar IDR cenderung terdepresiasi terhadap USD dalam jangka panjang. Di sisi lain, operational hedging tidak terbukti berpengaruh dalam mengurangi eksposur nilai tukar. Hal ini menunjukkan jaringan operasional yang dimiliki perusahaan di luar negeri ditujukan untuk kepentingan bisnis dan tidak dimaksudkan untuk diversifikasi risiko.

Adapun tentunya penelitian ini tidak luput dari berbagai kelemahan. Disarankan bagi peneliti selanjutnya yang hendak melakukan penelitian terkait pengaruh lindung nilai terhadap eksposur nilai tukar agar dapat mengembangkan proksi alternatif dari operational hedging. Hal ini dikarenakan proksi operational hedging pada penelitian ini memiliki beberapa keterbatasan seperti yang telah dipaparkan sebelumnya. Peneliti selanjutnya juga dapat menggunakan skala rasio untuk financial hedging, misalnya jumlah nosional transaksi derivatif terhadap total aset sehingga bukan saja mengidentifikasi apakah perusahaan menggunakan instrumen derivatif nilai tukar atau tidak, melainkan seberapa besar penggunaan instrumen derivatif tersebut. Kemudian, penelitian mendatang juga dapat menggunakan populasi berupa seluruh perusahaan 
yang terdaftar di Bursa Efek Indonesia sehingga hasil penelitian memiliki tingkat generalisasi yang lebih tinggi dan perbedaan jenis industri dapat diamati.

\section{REFERENCES}

Adler, M., dan Dumas, B. (1984). Exposure to Currency Risk: Definition and Measurement. Financial Management, 13(2), 41-50.

Allayannis, G., dan Ofek, E. (2001). Exchange Rate Exposure, Hedging, and The Use of Foreign Currency Derivatives. Journal of International Money and Finance, 20(2), 273-296.

Allayannis, G., Ihrig, J., dan Weston, J.P. (2001). Exchange-Rate Hedging: Financial Versus Operational Strategies. American Economic Review, 91(2), 391-395.

Bank Indonesia. (2014). Peraturan Bank Indonesia No. 16/21/PBI/2014 tentang Penerapan Prinsip Kehati-hatian dalam Pengelolaan Utang Luar Negeri Korporasi Nonbank. Didapatkan dari https://peraturan.bpk.go.id/Home/Details/135379/peraturan-bi-no-1621pbi2014.

Bank Indonesia. (2020). Laporan Perekonomian Indonesia Tahun 2019. Didapatkan dari https://www.bi.go.id/id/publikasi/laporan/Pages/LPI_2019.aspx.

Belghitar, Y., Clark, E., dan Mefteh, S. (2013). Foreign Currency Derivative Use and Shareholder Value. International Review of Financial Analysis, 29, 283-293.

Bodnar, G. M., dan Wong, M. H. F. (2003). Estimating Exchange Rate Exposures: Issues in Model Structure. Financial Management, 32(1), 35-67.

Carter, D. A., Pantzalis, C., dan Simkins, B. J. (2003). Asymmetric Exposure to Foreign-Exchange Risk: Financial and Real Option Hedges Implemented by US Multinational Corporations. Didapatkan dari https://papers.ssrn.com/sol3/papers.cfm?abstract_id $=387082$, 25 September 2020, pukul 11:25 WIB.

Chiang, Y. C., dan Lin, H. J. (2007). Foreign Exchange Exposures, Financial and Operational Hedge Strategies of Taiwan Firms. Investment Management and Financial Innovations, 4(3), 95-105.

Chue, T. K., dan Cook, D. (2008). Emerging Market Exchange Rate Exposure. Journal of Banking and Finance, 32(7), 1349-1362.

Hagelin, N., dan Pramborg, B. (2004). Hedging Foreign Exchange Exposure: Risk Reduction from Transaction and Translation Hedging.
Journal of International Financial Management and Accounting, 15(1), 1-20.

Hutson, E., dan Laing, E. (2014). Foreign Exchange Exposure and Multinationality. Journal of Banking and Finance, 43(1), 97-113.

Indawan, F., Fitriani, S., Karlina, I., dan Grace, M. V. (2015). The Role of Currency Hedging on Firm Performance: A Panel Data Evidence in Indonesia. Buletin Ekonomi Moneter Dan Perbankan, 17(3), 279-298.

Ito, T., Koibuchi, S., Sato, K., dan Shimizu, J. (2016). Exchange Rate Exposure and Risk Management: The Case of Japanese Exporting Firms. Journal of the Japanese and International Economies, 41, 17-29.

Jorge, M. J. D. S., dan Augusto, M. A. G. (2011). Financial Risk Exposures and Risk Management: Evidence from European Nonfinancial Firms. Revista de Administracao Mackenzie, 12(5), 68-97.

Jorion, P. (1990). The Exchange-Rate Exposure of U.S Multinationals. The Journal of Business, 63(3), 331-345.

Jorion, P. (2011). Financial Risk Manager Handbook 6th Edition. Hoboken: John Wiley \& Sons, Inc.

Kim, Y. J., Tesar, L., dan Zhang, J. (2015). The Impact of Foreign Liabilities on Small Firms: FirmLevel Evidence from the Korean Crisis. Journal of International Economics, 97(2), 209-230.

Kedia, S., dan Mozumdar, A. (2003). Foreign Currency Denominated Debt: An Empirical Examination. The Journal of Business, 76(4), 521546.

Kementerian Keuangan Republik Indonesia dan Bank Indonesia. (2020). Statistik Utang Luar Negeri Indonesia Volume XI Maret 2020. Didapatkan dari https://www.djppr.kemenkeu.go.id/uploads/files/SULNI/Buku\%20Statistik\%20Utang\%20Luar\%20Negeri\%20Indonesia\%20Edisi\%20Maret\%202020.pdf.

Kementerian Keuangan Republik Indonesia dan Bank Indonesia. (2014). Statistik Utang Luar Negeri Indonesia Volume V Desember 2014. Didapatkan dari https://www.djppr.kemenkeu.go.id/uploads/files/dmodata/in/5Statistik/9BukuStatistik_ULN/SULNI\%20Desember\%2014.pdf.

Madura, J. (2018). International Financial Management (Edisi ke-13). Boston: Cengage Learning.

Pantzalis, C., Simkins, B. J., dan Laux, P. A. (2001). Operational Hedges and The Foreign Ex- 
change Exposure of US Multinationals Corporations. Journal of International Business Studies, 32(4), 793-812.

Purnamawati, A., dan Fatmawati, S. (2013). DasarDasar Ekspor Impor. Yogyakarta: UPP STIM YKPN.

Smith, C. W., dan Stulz, R. M. (1985). The Determinants of Firms Hedging Policies. Journal of Financial and Quantitative Analysis, 20(4), 391-405.

Stulz, R. M. (1996). Rethinking Risk Management. Journal of Applied Corporate Finance, 9(3), 825.

Suriawinata, I. S. (2004). Apakah Kebijakan Hedging Perusahaan dengan Instrumen Derivatif Valuta Asing Meningkatkan Nilai Pemegang Saham? Bukti Empiris dari Perusahaan-Perusahaan Non-Finansial yang Terdaftar di Bursa Efek Jakarta. Jurnal Manajemen Prasetiya Mulya, 9(2), 59-80.

Widarjono, A. (2013). Ekonometrika: Pengantar dan Aplikasinya. Yogyakarta: UPP STIM YKPN 


\section{LAMPIRAN}

\begin{tabular}{|c|c|c|c|c|c|c|c|c|c|c|}
\hline \multicolumn{11}{|c|}{ POSISI UTANG LUAR NEGERI INDONESIA MENURUT KELOMPOK PEMINJAM TAHUN 2009 - 2018} \\
\hline & & & & & & & & & alam juta & an USD) \\
\hline \multirow{2}{*}{ Utang Luar Negeri } & \multicolumn{2}{|c|}{2009} & \multicolumn{2}{|c|}{2010} & \multicolumn{2}{|c|}{2011} & \multicolumn{2}{|c|}{2012} & \multicolumn{2}{|c|}{2013} \\
\hline & Jumlah & $\%$ & Jumlah & $\%$ & Jumlah & $\%$ & Jumlah & $\%$ & Jumlah & $\%$ \\
\hline $\begin{array}{ll}\text { Pemerintah dan } \\
\text { Bank Sentral }\end{array}$ & 99.265 & $57,42 \%$ & 118.624 & $58,60 \%$ & 118.642 & $52,64 \%$ & 126.119 & $49,98 \%$ & 123.548 & $46,43 \%$ \\
\hline Swasta & 73.606 & $42,58 \%$ & 83.789 & $41,40 \%$ & 106.732 & $47,36 \%$ & 126.245 & $50,02 \%$ & 142.561 & $53,57 \%$ \\
\hline $\begin{array}{l}\text { Lembaga Keu- } \\
\text { angan }\end{array}$ & 12.596 & $7,29 \%$ & 17.957 & $8,87 \%$ & 24.570 & $10,90 \%$ & 30.730 & $12,18 \%$ & 32.378 & $12,17 \%$ \\
\hline Bank & 9.530 & $5,51 \%$ & 14.382 & $7,11 \%$ & 18.466 & $8,19 \%$ & 23.018 & $9,12 \%$ & 24.431 & $9,18 \%$ \\
\hline $\begin{array}{l}\text { Bukan Bank } \\
\text { Bukan Lembaga }\end{array}$ & 3.066 & $1,77 \%$ & 3.575 & $1,77 \%$ & 6.103 & $2,71 \%$ & 7.713 & $3,06 \%$ & 7.947 & $2,99 \%$ \\
\hline Keuangan & 61.009 & $35,29 \%$ & 65.833 & $32,52 \%$ & 82.162 & $36,46 \%$ & 95.515 & $37,85 \%$ & 110.183 & $41,41 \%$ \\
\hline $\begin{array}{l}\text { Total Utang Luar } \\
\text { Negeri }\end{array}$ & 172.871 & $100 \%$ & 202.413 & $100 \%$ & 225.375 & $100 \%$ & 252.364 & $100 \%$ & 266.109 & $100 \%$ \\
\hline
\end{tabular}

\begin{tabular}{|c|c|c|c|c|c|c|c|c|c|c|}
\hline \multicolumn{11}{|c|}{ (dalam jutaan USD) } \\
\hline \multirow{2}{*}{ Utang Luar Negeri } & \multicolumn{2}{|c|}{2014} & \multicolumn{2}{|c|}{2015} & \multicolumn{2}{|c|}{2016} & \multicolumn{2}{|c|}{2017} & \multicolumn{2}{|c|}{2018} \\
\hline & Jumlah & $\%$ & Jumlah & $\%$ & Jumlah & $\%$ & Jumlah & $\%$ & Jumlah & $\%$ \\
\hline Pemerintah dan & 36 & 44 & 0 & $4589 \%$ & 83 & 494 & 180622 & 512 & 186275 & $4962 \%$ \\
\hline Swasta & 163.592 & $55,77 \%$ & 168.123 & $54,11 \%$ & 161.722 & $50,54 \%$ & 171.847 & $48,76 \%$ & 189.155 & $50,38 \%$ \\
\hline $\begin{array}{l}\text { Lembaga Keu- } \\
\text { angan }\end{array}$ & 41.822 & $14,26 \%$ & 42.997 & $13,84 \%$ & 40.062 & $12,52 \%$ & 40.563 & $11,51 \%$ & 44.953 & $11,97 \%$ \\
\hline Bank & 31.673 & $10,80 \%$ & 31.920 & $10,27 \%$ & 30.247 & $9,45 \%$ & 30.300 & $8,60 \%$ & 34.367 & $9,15 \%$ \\
\hline $\begin{array}{l}\text { Bukan Bank } \\
\text { Bukan Lembaga }\end{array}$ & 10.149 & $3,46 \%$ & 11.077 & $3,56 \%$ & 9.815 & $3,07 \%$ & 10.263 & $2,91 \%$ & 10.586 & $2,82 \%$ \\
\hline Keuangan & 121.771 & $41,51 \%$ & 125.125 & $40,27 \%$ & 121.661 & $38,02 \%$ & 131.284 & $37,25 \%$ & 144.202 & $38,41 \%$ \\
\hline $\begin{array}{l}\text { Total Utang Luar } \\
\text { Negeri }\end{array}$ & 293.328 & $100 \%$ & 310.730 & $100 \%$ & 320.006 & $100 \%$ & 352.469 & $100 \%$ & 375.430 & $100 \%$ \\
\hline
\end{tabular}

Sumber: Statistik Utang Luar Negeri Indonesia Vol XI Maret 2020 dan Vol V Desember 2014 dipublikasikan Kementerian Keuangan Republik Indonesia bersama dengan Bank Indonesia 